\title{
PLAN AHEAD
}

for coming meetings of the

\section{Business History Conference}

1982

St. Paul, Minnesota

Host institution: The James J. Hill

Reference Library

(Joint meeting with the Lexington Group

and the Economic and Business

Historical Society)

\section{3}

Peoria, Illinois

Host institution: Bradley University

(Joint meeting with the Lexington Group)

For information about these meetings and membership in any of these organizations, write to:

Business History Conference: Prof. Jeremy Atack, Secretary, Department of Economics, Box 111, Commerce Building West, Urbana IL 61801 .

Lexington Group (transportation history) : Prof. Don L. Hofsommer, Dept. of History, Wayland College, Plainview TX 79072.

Economic and Business Historical Society (usually meets in the West): Prof. Philip R. Smith, Dept. of Social Science, Michigan State University, East Lansing MI 48824. 


\section{LABOR HISTORY}

Published by The Tamiment Institute

Original research in American labor history, studies of specific unions and of the impact labor problems have upon ethnic and minority groups, theory of labor history, biographical portraits of important trade union figures, comparative studies and analyses of foreign labor movements which shed light on American labor developments, studies of radical groups or of radical history related to American labor history.

LABOR HISTORY is published four times a year: in winter, spring, summer, and fall. Annual subscription: individuals, $\$ 15.00$; institutions, $\$ 17.50$; students, $\$ 10.00$; single copy, $\$ 4.00$. Add $\$ 1.50$ additional per year for foreign postage.

\section{LABOR HISTORY}

Bobst Library, Tamiment Institute

New York University

70 Washington Square South

New York, New York 10012

\section{Work Hazards and Industrial Conflict}

\section{CARL GERSUNY}

Hardly a day passes without reports on litigation over work injuries or conflicts over standards for hazardous substances. Concern for these conditions has been heightened by implementation of the Occupational Safety and Health Act. Gersuny contends that these events are properly understood in a socio-historical context. He argues that along with differences in power and privilege generated by the workplace go differences in hazard to life and limb, which are characteristics of class divisions. This thoughtful book on a controversial topic offers new ways of looking at a perennial problem. A University of Rhode Island book. $\$ 12.00$

\section{University Press of New England}

Hanover, New Hampshire and London, England 


\section{REPRINTS AVAILABLE}

\section{Business History Review}

Formerly: Bulletin of the Business

Historical Society, Boston

Vols. 1-43 and Gen. Ind. 1-30. Boston,

Mass., 1926-1969

Vols. 1-30 (in 15 units) ${ }^{\circ}$

cloth $\$ 923.00$

Vols. $31-43$

General Index

General Index 28-30

- Vols. 1-24 reprinted in units as follows:

$\begin{array}{rr}\text { cloth } & \$ 923.00 \\ \text { paper } & \$ 749.00 \\ \text { per unit paper } & \$ 25.00 \\ \text { per vol. paper } & \$ 28.00 \\ \text { paper } & \$ 7.00 \\ \text { paper } & \$ 3.00\end{array}$

$1 / 3(1926-29) ; 4 / 6(1930-32) ; 7 / 9(1933-35)$;

$10 / 12(1936-38) ; 13 / 15(1939-41) ; 16 / 18(1942-44)$;

$19 / 20(1945-46) ; 21 / 22(1947-48) ; 23 / 24(1949-50)$.

\section{Journal of Economic and Business History}

Vols. 1-4(all publ.). Cambridge, Mass., 1928/29-1931/32.

Order from:

KRAUS REPRINT CO

A U.S. Division of Kraus-Thomson Organiration Limited

Route 100

Millwood, New York 10546

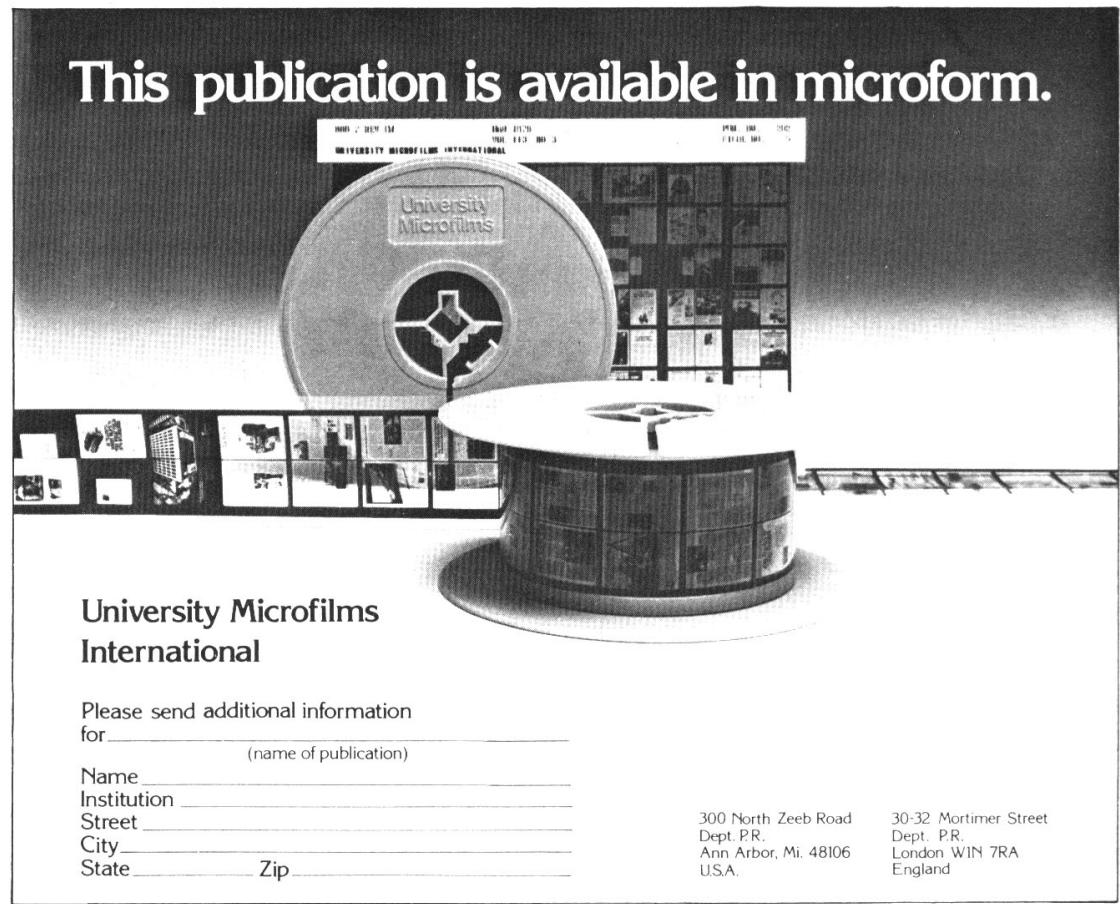




\section{Newcomen Awards in Business History}

For the best article published in the Business History Review during the previous year the Society will award a prize of $\$ 300$ and a scroll. For the best article published in the Business History Review during the previous year by a graduate student or a recent $\mathrm{Ph}$.D. who has not published a book in business history, the Society will award a special prize of $\$ 150$ and a scroll. Criteria for selection include: originality, value, breadth, and interest of contribution, quality of research materials and methods, and quality of presentation.

Winners will be selected by a panel of judges consisting of the editor, associate editor, and members of the advisory board of the Business History Review, none of whom shall be eligible to receive a prize. The awards are administered by the editorial office of the Review. No special prize will be awarded in years when, in the opinion of the judges, no eligible article suitable for the prize was published, and no person may be awarded both prizes in any one year.

ANNOUNCING
THREE AWARDS
IN
BUSINESS HISTORY

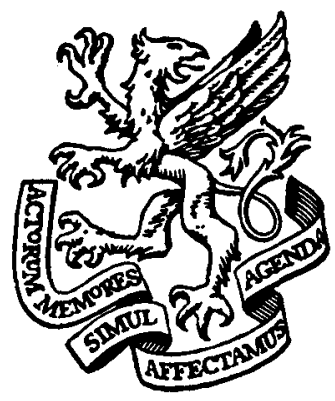

PRESENTED BY THE NEWCOMEN SOCIETY IN NORTH AMERICA

\section{Thomas Newcomen Book Award in Business History}

The Newcomen Society in North America, in cooperation with the Business History Review, will award in 1982 the seventh in a series of triennial prizes consisting of $\$ 1000$ and a scroll for the best book on the history of business published in the United States during the years 1979-1981. "Business history" is defined in its broadest sense to include not only the history of firms or industries, but books tracing interactions of businessmen, analyses of business philosophy or behavior, and studies of the adjustment of businesses and businessmen to their economic, political, and social environments. Criteria for selection will include contribution to knowledge, depth of analysis, soundness of reasoning, clarity of style and organization, and general readability and format.

Judges for the 1982 award are Dr. Albro Martin, Editor, Business History Review, chairman, and Professor Alfred D. Chandler, Jr., both of the Harvard Graduate School of Business Administration; and Mr. Stanley van den Heuvel, Trustee, The Newcomen Society in North America. 

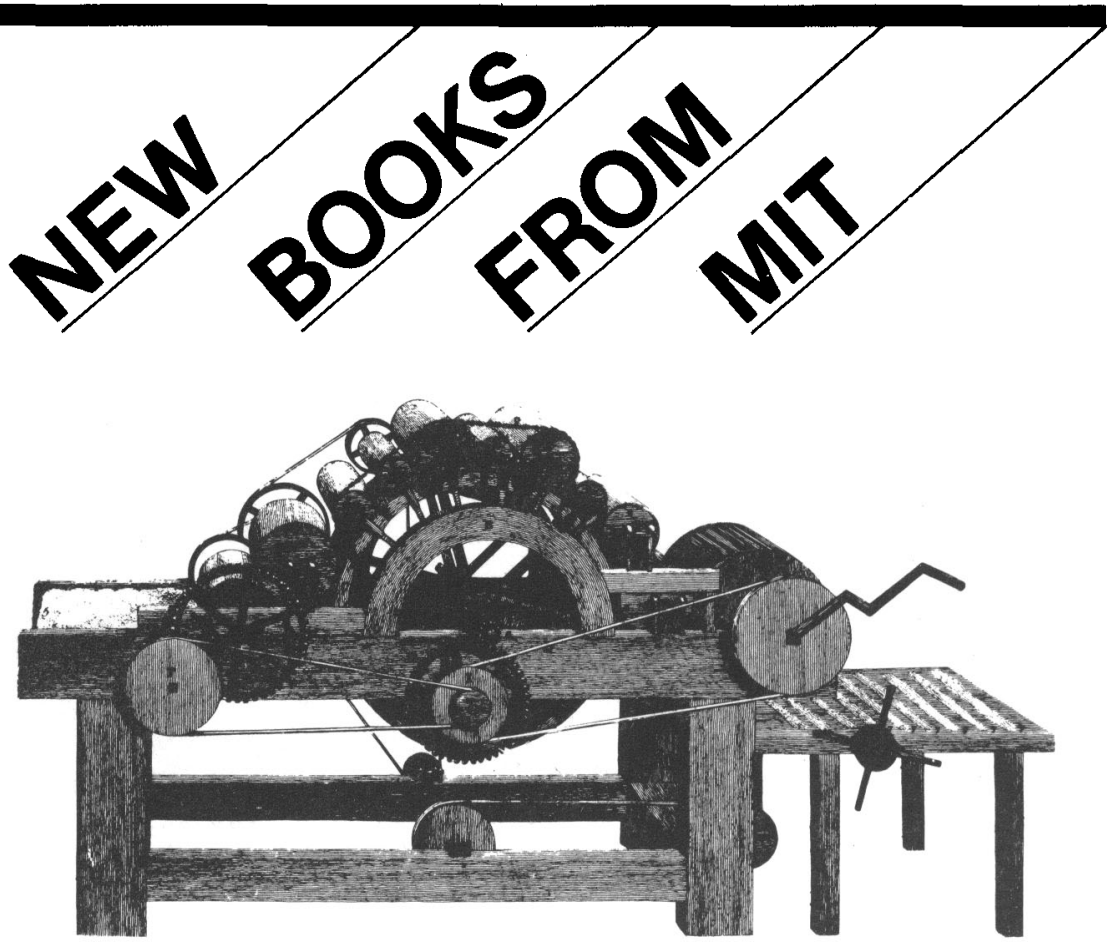

TRANSATLANTIC INDUSTRIAL REVOLUTION:

The Diffusion of Textile Technologies between Britain and America, 1790-1830s

by David J. Jeremy

This book examines the transfer of four specific technologies: cotton spinning, powerloom weaving. calico printing, and woollen manufacturing. It is firmly based on modern economic theory and well illustrated with halftones and line drawings.

David J. Jeremy is a Research Fellow in the Business History Unit at the London School of Economics and Political Science and joint editor of the recently launched Dictionary of Businéss Biography. On this side of the Atlantic, he has served as Curator at the Merrimack Valley Textile Museum in Massachusetts.

"Impressive for its mastery of textile technology, Jeremy's book also addresses broader problems: what conditions facilitate or hinder the transfer of technology between countries; how technologies are modified during the process of transfer; how appropriate technologies are found for a developing country where factor proportions and social conditions differ from those in the country of origin. Its command both of technical detail and of analyt ical problems gives this book a unique value and commends it to the attention of all serious students of technological change"-Professor Hugh G.J. Aiken. Department of Economics. Amherst College

384 pages-illus - $\$ 32.50$

\section{Forthcoming}

\section{THE PHILOSOPHY OF MANUFACTURES}

edited by Michael Folsom and Steven Lubar

This first volume in the series. Documents in American Industrial History, collects the primary texts in the American debate over industrialization between the Revolution and the Civil War. In particular, these reflect the intellectual and ideological forces behind the promotion of manufactures, revealing much about the shaping of our fundamental institutions as the new democracy responded to industrialization.

\section{The MIT Press}

